\title{
Satisfaction from Online Education among Undergraduate Students of Health Sciences in Punjab during Covid-19; An Online Survey
}

\author{
Nadia Saleem ${ }^{1}$, Tahir Mahmood ${ }^{2}$, Komal Tariq $^{3}$, Umer Maqsood ${ }^{4}$
}

\begin{abstract}
Assistant Professor, Bakhtawar Amin College of Rehabilitation Sciences, Bakhtawar Amin Medical and Dental College, 1 Multan Pakistan

Conception $\mathcal{E}$ design, Final approval $\mathcal{E}$ guarantor of the article, Critical revision of the article for more important intellectual content

2 Senior Lecturer/Physiotherapist, Agile Institute of Rehabilitation Sciences, Bahawalpur Pakistan

2 Drafting of the article, Conception $\mathcal{E}$ design analysis, Interpretation $\mathcal{E}$ Statistical expertise

3 Lecturer/Physiotherapist, Faisal Institute of Health Sciences, Faisalabad Pakistan

3 Analysis, Interpretation \& Statistical expertise

4 Assistant Professor, Azra Naheed Medical College, Department of Physical Therapy, Superior University, Lahore Pakistan

4 Collection $\&$ assembly of data Statistical expertise
\end{abstract}

CORRESPONDING AUTHOR

Dr. Nadia Saleem (PT)

Assistant Professor, Bakhtawar Amin College of Rehabilitation Sciences, Bakhtawar Amin

Medical and Dental College, Multan Pakistan

Email: nadiasaleem256@gmail.com

Submitted for Publication: 08-02-2021 Accepted for Publication 18-02-2021

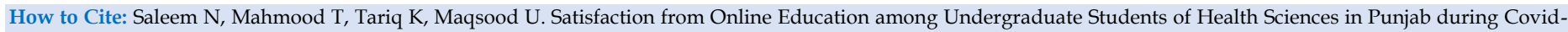
19-An Online Survey. APMC 2021;15(1):82-5. DOI: 10.29054/APMC/2021.1171

\section{ABSTRACT}

Background: The lockdown strategy has been implemented globally to contain the spread of current pandemic of COVID19. Educational institutes around the globe are facing challenges and online learning is being carried out to avoid face to face contact during lockdown. Students have to adapt entirely new methods of learning through information technology. Objective: To assess the satisfaction level of health science students with online learning and use of internet during Covid19 lock down in Punjab. Study Design: Cross-sectional survey. Settings: The data was collected from different institutes of Punjab using an online survey. Duration: Three months from May 2020 to July 2020. Methodology: A convenient sample of sample $(\mathrm{N}) 357$ undergraduate medical students were included based on the response submitted through online questionnaire. Volunteer undergraduate students of MBBS, BDS, DPT, and Pharm D were included. The level of satisfaction was measure using Online Learning/Distance Education Questionnaire. Data was evaluated by SPSS version 22. Frequency tables and percentages was used to measure categorical variables. Results: 41 were males and 316 Females with mean age of 20.5 $\pm 8.5 .15 .6 \%$ Most of them had taken more than 03 courses online on computer for educational purpose. More than half students responded that they were motivated to attend online lectures. $23.52 \%$ thought that they can pass any course is on internet-based study. $27.45 \%$ considered online and in physical classes as same. The access of internet was not issue for $50.98 \%$ students and $37.53 \%$ think that course can be completed online. Conclusion: The students were satisfied from online education during this time of transition of conventional classes to online classes. More than half of them felt no issue of internet and $37 \%$ think that course can be completed in this mode of education.

Keywords: Distance learning, Health sciences, Online learning, Student satisfaction, Undergraduate students.

\section{INTRODUCTION}

The global impact of covid-19 outbreak not only effected human's life style but it has also transformed the word in to changed modes of communication. Every aspects of life have to be changed including social work, travelling and universities education system. The education sector including health sciences used their resources to keep the education system ongoing. The distance learning was launched to facilitate the students. ${ }^{1}$ But in case of educational programs and practical learning mode of delivery has been transferred to digital resources to avoid gatherings. But the availability of internet sources and access of remained an issue for institutes. ${ }^{2}$ Internet and relative digital gadgets are most important tool for communication among class fellows and with instructor. Majority of medical institution of Pakistan still have not been equipped with modern information technology. HEC is still reluctant in adopting modern technologies in medical education. ${ }^{3}$ Online education emerged in medical and rehabilitation education due to covid-19 outbreak in February 2020 in Pakistan. Government of Pakistan has replaced traditional education with elearning technology as an alternative tool. It is the emergence of distance learning by using pedagogical model through modern information technologies for interaction with fellows and instructor in remote locations. ${ }^{4}$ E-learning defined as the transformation of knowledge through electronic devices involves laptop, mobiles and other electronic gadgets to interact with teachers and other student fellows for learning. ${ }^{5}$ Internet provides advance information and prepares health care professionals with update use of different techniques as well as treatment regimen. That is more considered in critical environment to overcome natural crisis from time to time. But when there is lack of Practical sessions including techniques of rehabilitation and other hands on practical techniques, that is a subject of reconsideration. ${ }^{6}$ On the other hand utilizing electronic health record, 
digital data bases and advanced communication technology always remained helpful to meet the challenges of learning and diagnosis during pandemic (Covid-19).7 In online education the Instructor plays a key role in this learning process, in the form of shaping the leaning activities and supporting in ease of sharing of the knowledge. This is more independent learning than traditional on campus teaching. ${ }^{8}$ Online teaching has multiple benefits; lecture may be recorded and being watched on convenient time and repeated multiple times for full understanding any time. It can be shared with student of different areas and countries to improve the knowledge deficiencies from time to time. Keeping the teacher's perspective and student satisfaction, comfortable learning and experience is very important to evaluate. ${ }^{9}$ The lecture can be optimized so that it is of the best quality possible. Teachers can use the opportunity to record the lecture at their convenience when resources are present $^{10}$ Simulation and rehearsal of different clinical scenario for medical students is mandatory. E-learning is potentially efficient to deliver theoretical knowledge that underpins abilities of communication skills. Simulation of virtual patient is useful but it is very difficult to replicate the standard patient. ${ }^{11}$ Many studies are in favor of the statement that there are not any specific differences exists in online or physical classes at institute with traditional methods of teaching ${ }^{12}$ Institutes tried their best to overcome these issues but it cannot be denied that teaching method of instructor, student interaction and content delivered is important consideration during such an environment. ${ }^{13}$

Due to deficiency of such study different institutes on large sample, the study aimed was to measure satisfaction level of students and issues faced by them in online education system. As we have many areas where internet facilities are available in limited range. Despite of hard work from institutes, HEC and instructors it was necessary to know about the student's perception about it. The study will definitely will help to address the issue of students and measures will be taken to improve it in future.

\section{METHODOLOGY}

Study Design: Cross-sectional survey.

Settings: The data was collected using an online survey during the lock down. The data was collected from different institutes of Punjab Pakistan.

Duration: Three months from May 2020 to July 2020.

Sample Technique: Convenient sampling technique.

Sample Size: 357 undergraduate medical students.

Inclusion Criteria: The response was recorded and after screening of the responses. Volunteer undergraduate students of MBBS, BDS, DPT, and Pharm-D were included.

Exclusion Criteria: Students who refused to participate and with any visual disorder were excluded.
Data Collection Procedure: Ethical Approval taken from Superior University Lahore. The data was collected from the students of public and private institutes of Punjab including: The University of Lahore (UOL), Multan Medical and Dental College, Muhammad Institute of Medical and Allied Health sciences, Multan, Agile institute of rehabilitation sciences (AIRS), Quaid-e-Azam Medical College, Bahawalpur, Shahida Islam Medical and Dental college, Lodhran, Ghazi Medical College, D.G. Khan, Govt. College university campus, Layyah, and Sheikh Zayed Medical college Rahim Yar khan. The data collection document includes an informed consent showing the voluntarily participation. The second part have basic demographic data including age, gender, department, number of courses and time spent on internet for education purpose. The level of satisfaction was measured using Online Learning/Distance Education Questionnaire. ${ }^{14}$ The questionnaire has different statements including internet access, about online lectures, course completion and other usage of Internet in education purpose. Convenient sampling technique used to select participants. Out of 470, completed questionnaires (N) 357 were included based on the response submitted. Data was analyzed with the help of SPSS version 25. Frequency tables, percentages and graphs were used to measure the outcomes.

\section{RESULTS}

In our study 41 were males and 316 Females with mean age of 20.5 \pm 8.5 . The Most participants were from The University of Lahore (44.26\%), Agile Institute of Rehabilitation Sciences Bahawalpur (18.67\%), Bakhtawar Amin medical and Dental College (10.36\%) and Riphah International University (15.6\%). Most of them had taken more than 03 courses online (56\%) and spent 1-5 (35.3\%) hours and 6-10 hours per week (31.4\%) for educational purpose. Table 1

Table 1: Participants Details

\begin{tabular}{|l|c|c|c|}
\hline \multicolumn{1}{|c|}{ General Data } & Category & Frequency & Percentage \\
\hline \multirow{2}{*}{ Gender } & Male & 41 & $11.4 \%$ \\
\cline { 2 - 4 } & Female & 316 & $88.51 \%$ \\
\hline Number of Distance & 0 & 17 & $4.76 \%$ \\
\cline { 2 - 4 } $\begin{array}{l}\text { Education or Online } \\
\text { Courses I have taken for }\end{array}$ & 1 & 75 & $21.08 \%$ \\
\cline { 2 - 4 } University credit & 2 & 65 & $18.20 \%$ \\
\cline { 2 - 4 } & $3+$ & 200 & $56.02 \%$ \\
\hline \multirow{2}{*}{$\begin{array}{l}\text { Estimated number of } \\
\text { hours I spend per week } \\
\text { using a computer for } \\
\text { educational purposes }\end{array}$} & $<1$ & 30 & $8.4 \%$ \\
\hline \multirow{3}{*}{ Age } & $1-5$ & 128 & $35.3 \%$ \\
\cline { 2 - 4 } & $6-10$ & 114 & $35.85 \%$ \\
\cline { 2 - 4 } & $>10$ & 85 & $23.8 \%$ \\
\cline { 2 - 4 } & $17-20$ & 115 & $32.15 \%$ \\
\cline { 2 - 4 } & $21-25$ & 201 & $56.30 \%$ \\
\hline
\end{tabular}

The student responded $54.34 \%$ were motivated to attend lectures outside of conventional class rooms. $56.86 \%$ thought that it is more discussable. $54.90 \%$ appreciated 
online group working. $23.52 \%$ thought that they can pass any course is on internet-based study. $52.10 \%$ I believe an Internet course is possible but for learning in English it would be difficult. $27.45 \%$ considered online and in physical classes as same. Table 2

Table 2: Student Response - Internet as source of Online Learning

\begin{tabular}{|c|c|c|c|c|}
\hline $\begin{array}{c}\text { Questions Asked from } \\
\text { Students }\end{array}$ & Agree & \begin{tabular}{|c|}
$\begin{array}{c}\text { Strongly } \\
\text { agree }\end{array}$ \\
\end{tabular} & Disagree & \begin{tabular}{|l}
$\begin{array}{l}\text { Strongly } \\
\text { disagree }\end{array}$ \\
\end{tabular} \\
\hline $\begin{array}{l}\text { I am motivated by the } \\
\text { material in an Internet } \\
\text { activity outside of class }\end{array}$ & 194 & 43 & 98 & 16 \\
\hline $\begin{array}{l}\text { I can discuss with other } \\
\text { students during Internet } \\
\text { activities outside of class }\end{array}$ & 203 & 35 & 93 & 17 \\
\hline $\begin{array}{l}\text { I can work in a group during } \\
\text { Internet activities outside of } \\
\text { class }\end{array}$ & 196 & 34 & 97 & 20 \\
\hline $\begin{array}{l}\text { I can collaborate with other } \\
\text { students during Internet } \\
\text { activities outside of class }\end{array}$ & 213 & 30 & 82 & 22 \\
\hline $\begin{array}{l}\text { Learning is the same in class } \\
\text { and at home on the Internet }\end{array}$ & 98 & 24 & 100 & 128 \\
\hline $\begin{array}{l}\text { I can practice English } \\
\text { grammar during Internet } \\
\text { activities outside of class }\end{array}$ & 199 & 22 & 104 & 26 \\
\hline $\begin{array}{l}\text { I believe that learning on the } \\
\text { Internet outside of class is } \\
\text { more motivating than a } \\
\text { regular course }\end{array}$ & 105 & 23 & 116 & 105 \\
\hline $\begin{array}{l}\text { I could pass a course on the } \\
\text { Internet without any } \\
\text { assistance (except normal } \\
\text { lectures) }\end{array}$ & 84 & 18 & 169 & 80 \\
\hline $\begin{array}{l}\text { I believe an Internet course } \\
\text { is possible but for learning } \\
\text { in English it would be } \\
\text { difficult. }\end{array}$ & 186 & 25 & 112 & 26 \\
\hline
\end{tabular}

The access of internet was not issue for $50.98 \%$ students, while $22.12 \%, 7.84 \%$ disagree and strongly disagreed respectively. Figure 1

Figure 1: I am able to easily access the Internet as needed for my studies

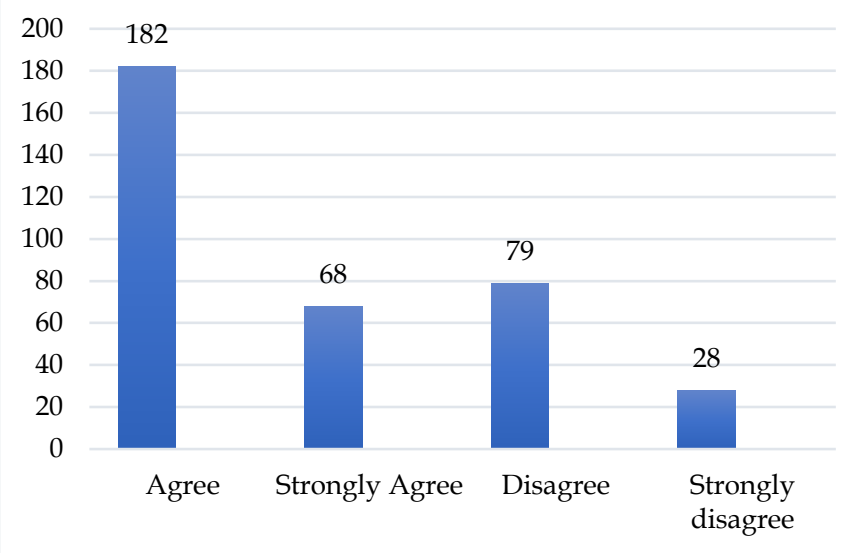

$37.53 \%$ think that course can be completed online while $22.12 \%$ were not agreed on it (Figure 2)

Figure 2: Course work can be completed given during online study without any difficulty

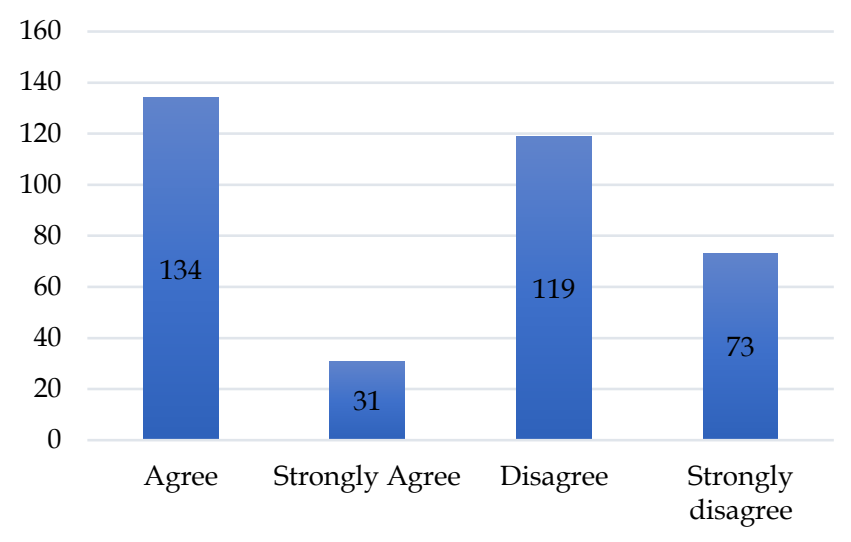

\section{DISCUSSION}

This cross-sectional survey was conducted in health sciences institutes of Punjab on a sample of 357 where 316 were females and 41 males completed the survey. The most of the participants were from UOL and AIRS Bahawalpur. 54. $34 \%$ were motivated to attend online lectures while $54.90 \%$ appreciated it. Student responded that they can pass course in online education system (23.52) In a local study in Lahore in last year stated that students were $51.9 \%$ spent their 1-5 hours / week on use of internet for study purpose and $29.7 \%$ had access to internet, ${ }^{14}$ but in our survey, it was $35.3 \%$ spent $1-5$ hours and $50.98 \%$ had access to internet respective comparison On other side more than $30 \%$ still had faced internet access issue which cannot be ignored. The developed countries have changed the methods of higher education over few decades. Students have high IQ and little desired to read long text and using internet-based system for interactive format of learning. ${ }^{15}$ In our survey that male participations were $11.4 \%$ and female $88.5 \%$. In online learning programs female's participation was more compared to the males in USA. ${ }^{16}$ In current study $27.45 \%$ felt it like regular classes and $50.98 \%$ faced internet technical issues as well like previous study. Comparing it with another study in Pakistan, showed 9\% student likely to remember the material taught in online classes but $20 \%$ think that it was same like regular classes. The technical issues were also faced by $49 \%$ undergraduate students. ${ }^{17}$

On the other side instructors guidelines, knowledge and clarity of presentation is also important factor in successful implementation of online education system ${ }^{18}$ The online learning self-efficacy (OLSE), learner content and Learner -Instructor interaction is the key predictor of the satisfaction level among students, where learner content interaction was considered as significant 
predicator of the student level of satisfaction. ${ }^{19}$ The role of social media interaction can be a powerful tool for teaching and learning despite of disadvantages which is debatable. ${ }^{20}$ The role of internet as tool of learning in recent situations was topic of interest in these days due to demand of decrease social interaction and distancing among the community just to stop the spread of this viral infection.

The computer based or internet based frame work of teaching and instruction can be an integral part for learning, guidance and problem solving. The mixed learning with use of instructor lectures and use of Web as support is successful method with its advantages and disadvantages as well. 21,22

\section{CONCLUSION}

The students were satisfied from online education during this time of transition of conventional classed to online classes. More than half of them felt no issue of internet and $37 \%$ think that course can be completed in this mode of education. $52 \%$ responded that internet-based study is possible and they can pass the course.

\section{LIMITATIONS}

The study was limited to health sciences students and many other factors we have not considered that can affect the results.

\section{SUGGESTIONS / RECOMMENDATIONS}

In our study, more contribution was from females and they were undergraduates students from $1^{\text {st }}$ year to final years. Further studies on these factors can make the results challenging arising new facts.

\section{CONFLICT OF INTEREST / DISCLOSURE}

None declared.

\section{ACKNOWLEDGEMENTS}

We are thankful to Professor Dr. Javed Iqbal, General Surgeon and Ex-Principal Quaid-e-Azam Medical College Bahawalpur, Dr. Muhammad Hafeez (PT) from Agile Institute of Rehabilitation Sciences Bahawalpur, Dr. Huma Riaz, Associate Professor from Riphah College of Rehabilitation Sciences, Islamabad for their moral support and guidance in the study.

\section{REFERENCES}

1. Dhawan S. Online learning: A panacea in the time of COVID-19 crisis. J Edu Technol Systems. 2020;49(1):5-22.

2. Simonson M, Zvacek SM, Smaldino S. Teaching and Learning at a Distance: Foundations of Distance Education 7th Edition.

3. Sulehri MA, Anwar R. Role of Educational Technologies in Improving Student's Performance in Medical Education. APMC. 2014;8(2):131-5.
4. Kumar A, Kumar P, Palvia SCJ, Verma S. Online education worldwide: Current status and emerging trends. J Info Technol Appl Res. 2017;19(1):3-9.

5. Singh V, Thurman A. How Many Ways Can We Define Online Learning? A Systematic Literature Review of Definitions of Online Learning (1988-2018). Am J Distance Edu. 2019;33(4):289-306.

6. Pei $\mathrm{L}, \mathrm{Wu} \mathrm{H}$. Does online learning work better than offline learning in undergraduate medical education? A systematic review and meta-analysis. Med Edu Online. 2019;24(1):e1666538.

7. Triola MM, Friedman E, Cimino C, Geyer EM, Wiederhorn J, Mainiero C. Health information technology and the medical school curriculum. Am J Manag Care. 2010;16(12):54-6.

8. Crow J, Murray JA. Online Distance Learning in Biomedical Sciences: Community, Belonging and Presence. Adv Exp Med Biol. 2020;1235:165-78.

9. Paudel P. Online education: Benefits, challenges and strategies during and after COVID-19 in higher education. Int J Studies Educ. 2021;3(2):70-85.

10. Oliver D. Medical education and COVID-19: a personal view. Croat Med J. 2020;61(3):213-4.

11. Kyaw BM, Posadzki P, Paddock S, Car J, Campbell J, Tudor Car L. Effectiveness of Digital Education on Communication Skills Among Medical Students: Systematic Review and Meta-Analysis by the Digital Health Education Collaboration. J Med Internet Res. 2019;21(8):e12967.

12. Allen M, Bourhis J, Burrell N, Mabry E. Comparing student satisfaction with distance education to traditional classrooms in higher education: A meta-analysis. Am J Dist Educ. 2002;16(2):8397.

13. Gazza EA, Matthias A. Using student satisfaction data to evaluate a new online accelerated nursing education program. Eval Program Plann. 2016;58(1):171-5.

14. Hashim A, Mustafa I, Shahid S, Butt SS, Ali A. Students' satisfaction in online education programs among undergraduate physiotherapy students of Lahore during covid-19. Rawal Medi J. 2020;45(3):507-9.

15. Twenge JM. Generational changes and their impact in the classroom: teaching Generation Me. Medi Educ. 2009;43(5):398405.

16. Kuo YC, Walker AE, Belland BR, Schroder KE. A predictive study of student satisfaction in online education programs. Int Rev Res Open Distributed Learning. 2013;14(1):16-9.

17. Anwar A, Khan E, Nisar M, Din R, Azim S, Awan T. The Impact of Covid-19 Pandemic on Learning of Undergraduate Medical Students: A Cross-Sectional Study from Karachi. PAFMJ. 2020;70(6):1902-07.

18. Lee J. An exploratory study of effective online learning: Assessing satisfaction levels of graduate students of mathematics education associated with human and design factors of an online course. The Int Review Res Open and Distrib Learning. 2014;15(1):111-32.

19. Alqurashi E. Predicting student satisfaction and perceived learning within online learning environments. Distance Education. 2019;40(1):133-48.

20. Latif MZ, Hussain I, Saeed R, Qureshi MA, Maqsood U. Use of smart phones and social media in medical education: trends, advantages, challenges and barriers. Acta Informatica Medica. 2019;27(2):133-8.

21. Goodman J, Melkers J, Pallais A. Can online delivery increase access to education? J Labor Econ. 2019;37(1):1-4.

22. Song D, Oh EY, Rice M. Interacting with a conversational agent system for educational purposes in online courses. 10th International Conference on Human System Interactions. 2017;17:78-2. 